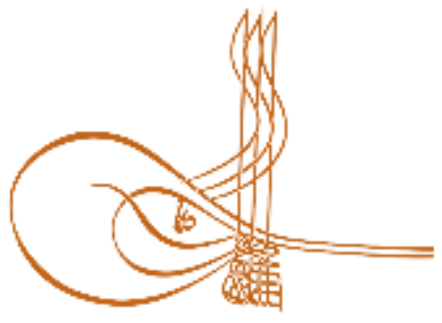

www.turkishstudies.net/social
Turkish Studies - Social Sciences

eISSN: $2667-5617$

Research Article / Araştırma Makalesi

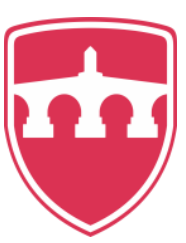

INTERNATIONAL

BALKAN

UNIVERSITY

Sponsored by IBU

\title{
Temel Sanat Eğitimi Dersinin Disiplinlerarası Gerekliliği Üzerine Bir Değerlendirme
}

\author{
An Evaluation on the Interdisciplinary Necessity of Basic Art Education Class
}

\author{
Zuhal Başbuğ $\breve{g}^{*}$
}

\begin{abstract}
Basic Art Education is one of the main courses of the fine arts programmes. In its curriculum, the main characteristics, principles, basic components and fundementals of art are treated and practical and theoretical information is given. Although it includes different characteristics in terms of programmes, it doesn't have big changes in practises. With contextual changes, Basic Art Education is a lesson that can be practised in different programmes. Although the object of the lesson is based on making individuals gain artistic abilities, on behalf of making use of fuctional features of art, especially in Turkey, it can be integrated into different programmes. Subjects such as composition, geometrical forms, basic drawing features that have a big importance among the basic principles of art are the main themes that adress every discipline. While teaching the interdisciplinarity of the basic art education lesson, the programmes that are prepared according to the needs of the branches, are important in that they include the basic principles and elements of art. At least some part of all the products and services thay are met in every pace of life contain the branches of design. So, the course hours should be organized according to the characteristics of the programme and should be placed according to the suitable class levels, and so individuals should take a specific art course. In this article, contextual features of Basic Art Education class in different programmes will be emphasized and with examples, an evaluation on its contribution to interdisciplinary programmes will be made.
\end{abstract}

Structured Abstract: Introduction When its art is analyzed by its general principles and elements, basic art education lesson, which questions color, tissue, composition ratio and proportion, makes use of different disciplines. Among these different disciplines, it enters the mathematics fieald with the structure of geometric figures, fine details in the raito and proportion calculation, composition layout so it needs concrete calculation of world of numbers and shapes. Considering the art education necessary for people's education contributes not only to art but also to other fields. The aim of this study is to emphasize the interdisciplinary necessity of basic art education.

According to Kırışoğlu (2002), "art education should exist at schools both as knowledge and experience to accomplish its own goal just like other subject areas". In this expression, the advantages of art education for individuals are ordered like these:

1. Art education enables the individual to communicate via art.

\footnotetext{
* Öğr. Gör. Dr., Akdeniz Üniversitesi, Güzel Sanatlar Fakültesi, Temel Eğitim Bölümü

Lec. Dr. Akdeniz Univercity, Faculty of Fine Arts, Basic Education Department

ORCID 0000-0001-6856-0432

zuhalbasbug@akdeniz.edu.tr

Cite as/ Atıf: Başbuğ, Z. (2020). Temel sanat eğitimi dersinin disiplinlerarası gerekliliği üzerine bir değerlendirme,

Turkish Studies - Social, 15(3), 995-1004. https://dx.doi.org/10.29228/TurkishStudies.41514

Received/Geliş: 29 January/Ocak 2020

Accepted/Kabul: 25 April/Nisan 2020

Checked by plagiarism software

Copyright $(C)$ INTAC LTD, Turkey

Published/Yayın: 30 April/Nisan 2020

CC BY-NC 4.0
} 
2. Art education gives the individual visual literacy.

3. Art education enables the person to have critical thinking towards qualitative awareness.

4. Art education allows the person to think and evaluate not only his own culture bot also other cultures.

5. Art education allows the person to have creative behaviour in transforming his /her image, thought or feeling.

6. It enables people to approach the society with a value judgement and as a social critic.

7. It enables the individuals to feel the pleasure of artistic productivity as a motive to create.

8. It has an important role of raising participant people in cultural and social development. (Kırışoğlu, 2002)

Many goals that are attributed to art are in fact the tools that helps visual thinking come out. Beauty, excellence and harmony can servet o give a kind of happiness by presenting a suitable world for human needs (Genç and Sipahioğlu, 1990).

Despite the fact that goals of art education and the behaviors that re meant to come out from people are not thought to be a service for different disciplines, its contributes to other disciplines prove that art education is a necessity. Learning to see can be thought as a interdisciplinary contribute that the art education will make. Seeing the details can be considered as a first step of the thinking on the way to solution. According to Berger (2016), seeing comes before speaking and even words.

\section{Findings}

The concept of interdisciplinary accepts that all the disciplines are rich, the are connected to each other and the real world problems don't have only one answer. Besides, the interdisciplinary concept keeps the contrary solutions about science, maths and language together and it features cognitive, affective and creative capacity to find better and newer ways to express opinions. This kind of affective and cognitive blend is usually peculiar to creative artist, scientist or phliosopher (Özkök from Perkins, 2005).

By eliminating the content limits to found interdisciplinary relationship in the curricula, it is very important to show how students are effected by different subject areas and to show the connection of the strong sides of every discipline to other disciplines (Özkök, 2005).

The branch of art that has a direct effect on preschool children's senses like drawing, sight and perception is valuable in that it makes great developments in the person's perception later on. Direct effect of art shows itself in the world of design. The concept of design is highly emphasized in basic art education lessons and from thinking to result every step to reach authentic designs is tought. The concept of design takes place not only in art but also in every field from every practical formation in daily life to technology.

Many teaching types can be classified as interdisciplinary, and it is possible to make this classification in art. As defined by Veronica Boix Mansilla ve Howard Gardner, the term 'interdisciplinary' includes interdisciplinary understanding intergration. According to this integration, it is not possible for one discipline to be enough for forms such as producing and problem solving that are special to various disciplines (Rhodes, 2006: 48).

Painting and music branches seem independent but they are based on same aesthetic and philosphic goals and concerns. When in all the branches of art there is a concern of composition or design, they have the concern of their arrangement items and producing process. Even though the material and the language change, the have the same concerns basically (Özdemir, İz-Bölükoğlu ve Şentürk, 2015). The main junctions of interdisciplinary programmes are seen as the form of doing collaborative work over determined concepts. The importance of basic art education includes how these concepts reflect on visual objects, how they turn into an objective property that are examined with the different viewpoints of artists and how the concrete objects are analyzed. Basic art education is a lesson that has a different content both in theory and practice and has active and dynamic norms. 


\section{Conclusion}

As a result; entegrating basic art education lesson to the interdisciplinary programmes will let people understand the basic elements of art such as dot, line, style, colour, spot, tissue and value; and the basic art principles such as balance, movement, rhythm, highlight, wholeness, contrast, variety, ratio and proportion and their effect on surfaces. Drawing techniques tought in basic art education lesson are very helpful in drawing and voluming biological structures in biology lessons. Similarly, art makes use of ratio and proportion in maths and basic dynamics of art contributes to mathematics. Art will make contribution to solve the relationship between form analysis and thinking based on problem solving and so it will contribute to focusing on solutions. Basic art education allows people to learn to see and this contibutes to their lives a lot. Nature analysis of naturalists and nature based works of basic art education contribute to each other. In this sense, contributions of basic art education in interdisciplinary works are no doubt will be positive.

The conributions of art education to interdisciplinary works are beyond argument. Besides, it helps people gain visual literacy and it is very important for social culture formation. To raise individuals who can quesiton and analyze the world thoroughly will be possible with basic art education.

As Bucciarelli (2016:15) stated; along with the contribute of art therapy to neurology, it is certain that it has an interdisciplinary relationship with psychotherapy, antrophology and other fields. In psychotherapy field, design based approach of basic art education contributes to interdisciplinary works. $\square \quad$ Giriş $\quad$ ve çalışmanın amacı (giriş ve araştırmanın amaç kısmında çalışmanın hangi soruya cevap aradığı, hangi araştırma sorusu ya da sorularından yola çıkıldığı ve bu çalışmanın niçin gerekli olduğuna ilişkin okuyucuda net fikir oluşumunu sağlayacak açıklıkta bilgiler verilmelidir)

Keywords: Basic art education, interdisciplinary, fine arts education.

Öz: Temel sanat eğitimi dersi, güzel sanatlar eğitimi veren programların ana derslerinden biridir. Ders müfredatında, sanatın temel özellikleri, ilkesi, bileşenleri ve esasları konu edinilerek uygulamalı ve teorik bilgiler verilmektedir. Programlara göre farklı özellikler barındırsa da uygulanan yöntemde büyük değişiklikler bulunmamaktadır. Temel sanat eğitimi dersi, içeriğinde yapılacak yeni düzenlemelerle farklı programlarda uygulanabilecek bir ders özelliğindedir. Dersin temel amacı, bireylere sanatsal yetiler kazandırma üzerine kurulu olsa da özellikle Türkiye'de sanatın işlevsel özelliğinden yararlanılması adına, farklı programlara entegre edilebilecek bir yapıya sahiptir. Sanatın temel disiplinleri arasında büyük öneme sahip kompozisyon, geometrik formlar, temel çizim özellikleri gibi konular, her disipline hitap eden başlıca konulardır. Bu ders sanatın temel ilke ve elemanların barındırdığı için; kompozisyon, renk, çizgi, leke, denge, ritm, oran orantı... vb unsurların kavratılması zaman alacaktır. Temel sanat eğitimi dersinin disiplinlerarası öğretiminde, alanların ihtiyaçlarına göre hazırlanan proğramlar, sanatın temel ilke ve elemanlarını içermesi açısından büyük önem taşımaktadır. Hayatın her alanında karşılaşılan tüm ürün ve hizmetlerinen en azından bir bölümü tasarım alanlarını da bünyesinde barındırmaktadır. Bu nedenle ders saati, program özelliklerine göre düzenlenerek uygun görülen sınıf düzeyine yerleştirilerek, bireylerin belirli bir sanat dersini almaları sağlanmalıdır. Bu makalede, temel sanat eğitimi dersinin farklı programlara göre içerik özellikleri üzerinde durularak, örneklerle disiplinlerarası programlara katkısı üzerinden bir değerlendirme yapılacaktır.

Anahtar Kelimeler: Temel sanat eğitimi, disiplinlerarası eğitim, güzel sanatlar eğitimi.

\section{Giriş}

Disiplinlerarası olarak nitelendirilen kavram, ayrı ayrı disiplinlerin zenginliğini, onların birbiriyle bağlantılı olduğunu, gerçek hayattaki problemlerin her zaman tek doğru cevabı olmadığını kabul etmektedir. Bununla birlikte disiplinlerarası kavramı, bilim, matematik ve dil gibi konularda karşıtlık içindeki çözümleri bir arada bulundurmak, düşünceleri ifade etmenin daha iyi ve yeni yollarını bulmak için bilişsel, duyuşsal ve yaratıcı kapasiteyi ön plana çıkarmaktadır. Genellikle, bu tür bir duygusal ve bilişsel karışım, yaratıcı sanatçı, bilim adamı ve düşünüre özgüdür (Perkins'den aktaran Özkök, 2005). 
Sanat ve bilim arasındaki ortaklık, geniş, kapsamlı tanımlarla, ayırt edilerek teorize edilmiştir. Bu işlem, çeşitli yöntem ve amaçlar bakımından resmi ayrımlar olarak ifade edilmektedir. Toplulukların kültürel yansımalarını, ürettikleri sanat eserlerini ortaya koyarken, nasıl oluştuklarını sosyal bilimlerin çeşitli alanları incelemektedir (Yang, 2011: 42). Sanat tarihi, antropoloji, arkeoloji gibi sanatın temel formlarını, yaratılış şeklini, kültürel yansımalarını araştıran farklı bilim alanları mevcuttur. Bununla birlikte tarih boyu sanat, çeşitli doğa, siyasi ve politik olayları, tarihsel şahsiyetleri, savaşları, coğrafi özellikleri yansıtan bir görsel nesne görevi üstlenmiştir. Sanat eserleri, sadece görsel olarak izlenen, anı yaşayan bir hobi aracı değildir. Tarihi, sosyolojik, psikolojik ve bilimsel bazı özellikleri vardır.

Temel sanat eğitimi dersi, içeriğindeki sanatın genel ilke ve elemanları noktasında incelendiğinde rengi, dokuyu, kompozisyonu, oran-orantıyı sorgulayan, irdeleyen yapısıyla farklı disiplinlerden yararlanmaktadır. Bu farklı disiplinler arasında geometrik şekillerin yapısını, oranorantı hesaplamasındaki ince detaylarda, kompozisyon yerleşim düzeyinde matematik alanına girerek sayı ve şekil dünyasının somut hesabına ihtiyaç duymaktadır (müzik, mimari, edebiyat, tıbbi bilimler, vb). Sanat eğitiminin bireylerin eğitiminde gereklilik olarak görmek, yalnızca sanata değil, diğer alanlara da katkı sağlayacak niteliktedir. Bu çalışmanın amacı; temel sanat eğitimi dersinin disiplinlerarası gerekliliğinin önemini vurgulamaktır.

Kırışoğlu (2002)'na göre "sanat eğitimi hem bilgi birikimi hem de deneyim olarak okullarda öteki konu alanları gibi kendi amaçlarını gerçekleştirmek için varolmalıdır”. Bu ifade şeklinde sanat eğitiminin bireylere sağlayacağı faydalar şu şekilde sıralanmıştır:

1. Sanat eğitimi, bireye sanat aracılığı ile iletişim kurma olanağı verir.

2. Sanat eğitimi, kişiye görsel okur- yazarlık kazandırır.

3. Sanat eğitimi, kişiye niteliksel ayrımsamaya yönelik eleştirel düşünme kazandırır.

4. Sanat eğitimi, kişiye kendi kültürünü olduğu kadar, öteki kültürleri öğrenme ve değerlendirme olanağı verir.

5. Sanat eğitimi, kişiye duygu, düşünü ve imgelerini bir ürüne dönüştürmede yaratıcı davranış kazandırır.

6. Sanatsal boyutta topluma değer yargısıyla ve de toplumsal bir kritik olarak yaklaşım yeteneği kazandırır.

7. Sanatsal üretim hazzını aynı zamanda yaratmanın bir güdüsü olarak bireylere tattırmak.

8. Kültürel ve toplumsal gelişmede katılımcı kişiler yetişmesinde önemli rol üstlenir (Kırışoğlu, 2002).

Sanata yakıştırılan birçok amaç, aslında görsel düşünmenin ortaya çıkmasını sağlayan araçlardır. Güzellik, mükemmellik ve uyum insan gereksinimlerine uygun bir dünya sunmak yoluyla bir tür mutluluk duygusu vermek için hizmet edebilir (Genç ve Sipahioğlu, 1990).

Sanat eğitiminin amaçları ve bireyler üzerinde gerçekleştirmesi beklenen davranışlar, farklı disiplinlere hizmet olarak düşünülmese bile, sonuç olarak farklı disiplinlere yapacağı katkılar sanat eğitiminin gereklilik olarak düşünülmesini sağlayacak niteliktedir. Görmeyi öğrenmek görsel sanat eğitiminin sağlayacağı, disiplinlerarası faydalardan biri olarak düşünülebilir. Ayrıntılarıyla görmek, çözüme giden üretim yolunda düşünmenin ilk basamağı olarak görülebilir. Berger (2016)'e göre görme, konuşmadan ve hatta sözcüklerden de önce gelmiş̧ir. Sanat eserlerini görmeyi öğrenmek, çevreyi görmeyi öğrenmekle birlikte ekolojiden yararlanmaktadır. 
Sanat eserleri, ilerleyen süreçte, ekolojik ilkelere ait örnekler ve gösteriler sunmuştur. Ancak, sanat süreçleri ve sanatçıların duyarlılıkları bazı durumlarda algı ve eylem çalışmalarında, sanat eserlerinden daha çok ilgi görmüştür (Keane, 2008: 343). Van Gogh'un kulağını kesmesi, Mona Lisa'nın çalınması, Frida'nın kaza geçirmesi gibi örnekleri çoğaltmak mümkündür. Böylece plastik sanatlar, edebi dile ve sinema alanına yansıyarak etki alanını genişletmektedir.

Pek çok öğretim türü disiplinlerarası olarak sınıflandırılırken, sanat alanında da bu sinıflandırmadan bahsetmek mümkündür. Veronica Boix Mansilla ve Howard Gardner tarafindan tanımlandığı şekliyle "disiplinlerarası" terimi, disiplinlerarası anlayış entegrasyonunu içermektedir. $\mathrm{Bu}$ entegrasyona göre ürün yaratmak, problem çözmek gibi çeşitli alana özgü biçimler için tek bir disiplinin yeterli olması mümkün değildir (Rhodes, 2006: 48).

Birçok disiplin, araştırma aşamasında yaratıcı düşünmeyi sanat ve tekniklerinden ödünç almaktadır. Aynı şekilde sanat, antropolojiyi etnografik dönüşümler konusunda esin kaynağı olarak görmektedir. Disiplinlerarası esneklik, sanat pratiklerine ulaşma konusunda önemli bir olgudur. Jelinek, sanatı nüanslı veya karmaşık öyküler yapma kapasitesi olarak değerlendirirken ona göre sanat, sonuçları ortaya koyan bir yöntem ve metodolojidir (Clarke, 2014: 179). Bu karmaşı gibi görünen metodoloji kavramı, tek bir sonuca varan gerçekliği tam olarak yansıtmasa da kişilere göre değişken bir anlam bütünlüğüne ulaşmaktadır.

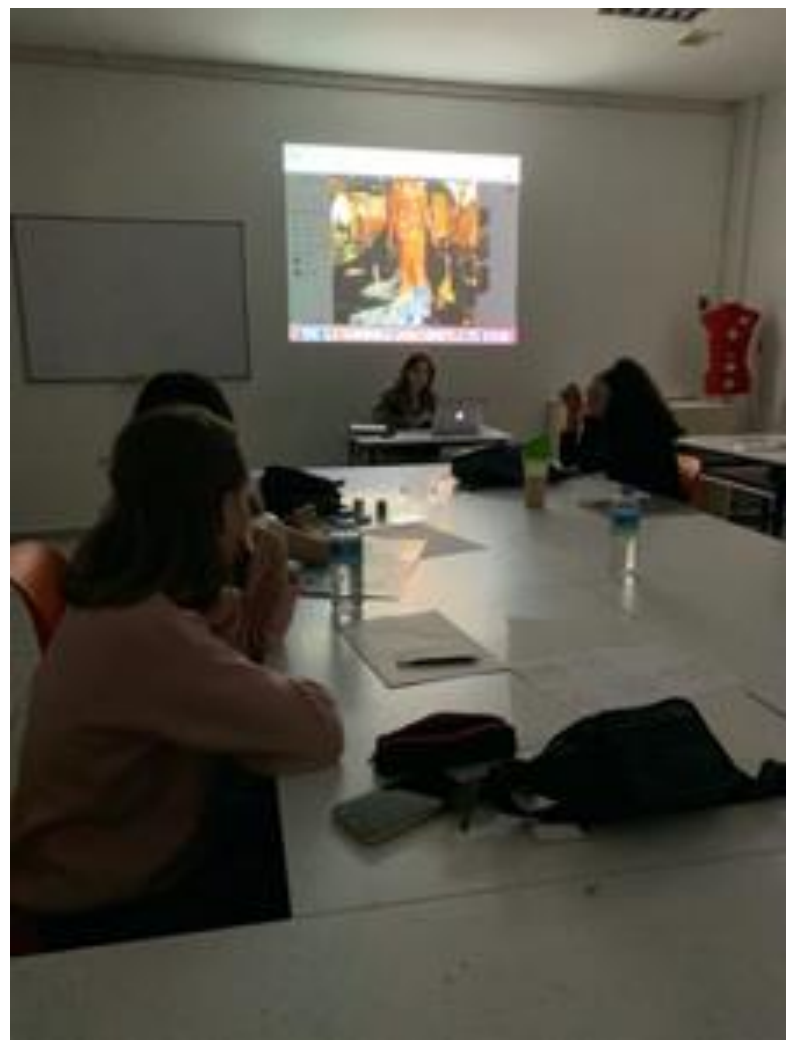

Görsel 1: Kıyafetler üzerindeki temel sanat ilke ve elamanlarının incelenmesi.

Modern Batı'da sanat, geleneksel olarak uzmanlık normlarına katılmış, yüksek kültür biçimi, himaye ve bireysel anlatım tarzıdır. Görüntüler ve nesneler, öncelikle müze, galeri ve halka açık olan alanlarda bulunan somut varlıklardır. Arkeologlar ve antropologlar sanatı, anlamların ve sembolik ifadelerin değeri olarak görmekte, sanatı yorumlama amacıyla (veya kod çözme) geleneksel sembolik olarak ifade edilen bir iletişim eylemi, yani basit form olarak değerlendirmektedir (DeMarrais ve Robb, 2013: 3). Arkeologların veya antropologların sanat hakkındaki bu tanımlaması, belirli bir sanat disiplini olgunluğuna ulaştıklarının ve çözümleme bilgisine sahip olduklarından 
kaynaklanmaktadır. Batılı ülkelerde sanat eğitimi, hemen her programda kendisine yer bulan, mutlak surette bireyi toplum estetiğine hazırlayan bir etkinlik olarak desteklenmektedir.

Sanat eğitimi, ülkelerin kilit politik eksikliklerini analiz etmede görsel sanatlar öğretmenlerine sorumluluk yüklemiştir (Bequette ve Brennan, 2008: 340-341). Kapitalist kültür tanımı, burada ortaya çıkarak, kendi kültür mekanizmasını farklı ülkelere yayan ve estetik bakışa yeni formlar getiren bir anlayışın temelini, sanat eğitimi üzerinden atmaktadır. Yıllar boyu, estetik konusunda Marksist söylemler dile getirilmektedir. Örneğin, Theodor Adorno, estetiği modern rejimin panzehiri olarak görmüştür. Adorno'ya göre araçsal düşünme, ekonomik sistemleri birbirinden ayırt ederek, yeni teknoloji kullanımında verimlilik ve stratejiler belirleyerek tek biçimli bir düşünce tarzını red, estetik anlayıșta böyle tek biçimli birleștiriciliğin olumsuzluğuna işaret etmektedir. Bourriaud, Frankfurt Okulu'nun “Arkaik folklor” kavramına eleştirel bir teori getirerek, Marksist estetik dalının kalıntılarının aktarıldığı sanat fikrini bir müdahale olarak düşünmektedir (Ross, 2006: 169). Estetiğin bu şekilde özel bir isimle kalıba sokulması, tek bir estetik fikrini dikte etmek olarak algılanmamalı, estetik hazzın ekonomiyle ilişkisi üzerinden farklı bir bakış açısıyla sosyalizme kayan bir metaya dönüştürülmesi olarak düşünülmelidir. Ancak burada önemli unsur, izleyicinin sanatı nasıl gördüğünden ziyade, sanat eserini oluşturan sanatçının bu konudaki görüşünün bu olguya dahil edilmesidir. Günümüz sanatında, sanat eseri oluşum sürecinde sadece sanatçının görüşü değil, farklı alanların bu oluşum sürecine katkısının sorgulanmasıda olaya dahil edilmektedir.

Sanatçılar, giderek daha dijital ve küresel bir kültürü yansıtmak için yeni yollar aradıklarında, farklı alanlarda bir işbirliği ve formlar arasında geçiş olması gerektiğine inanmışlardır. Dans, tiyatro, görsel sanat, film ve teknoloji gibi sanat alanlarının kendi içinde basit bir geçişkenliğe sahip olduğunu görmüşlerdir. Ortaya çıkan disiplinlerarası çalışma, daha zengin ve sanatçının rolünü daha olumlu yansıtması açısından önemlidir. Sanatın kendi arasındaki gibi disiplinlerarasındaki sınırları bulanıklaştırması, izleyici açısından daha keyifli bir gösteriye dönüşmektedir (Kennedy, 2009: 63). Buraya kadar ki görüşlerde sanat açısından farklı disiplinlerle etkileşimden söz edilmiştir. Plastik sanatların ana derslerinden biri olan temel sanat eğitimi dersinin diğer disiplinlere sağlayacağ 1 katkıdan söz etmekte yarar vardır.

\section{Temel Sanat Eğitimi Dersinin Disiplinlerarası Gerekliliği Üzerine Bir Değerlendirme}

Öğretim programlarında disiplinlerarası ilişkiyi sağlamak için içerik sınırlarını ortadan kaldırarak, öğrencilerin farklı ders konularının hayatlarını nasıl etkilediğini ve her disiplinin güçlü yanlarını diğerleriyle bağlantısını etkin biçimde göstermek çok önemlidir (Özkök, 2005).

Foucauldian'a göre, düşünmedeki bir dizi dönüşüm, disiplinlerarası gücü birleştirmekte ve büyütmektedir. Disiplinlerarası güncel gelişmeleri ortaya çıkaran bazı ana nedenler vardır. Bu nedenlerin en önemlilerinden biri bütünlüğü kavrama arzusu, her açıdan her şeyi daha iyi anlayabilmek için görme arzusu şeklindedir. Julie Thompson Klein bu arzuyu, herzaman bizimle birlikte olan bir arzu olarak tanımlamaktadır. Antik Yunan, orta çağ Hıristiyan felsefesinde, evrensel aydınlanma hırsı, aklı en önemli materyal olarak görmüştür. Akıl kavramı, akademik araştırmalarda karşılaşılan ve akademisyenleri disiplinlerarası alanlarda beraber çalışmaya teşvik eden mantığın kullanım etkisidir. Disiplinlerarasılık, İngiltere'de desteklenen ve yürürlükteki etki gündemiyle uyumlu bulunan bir çalışma şeklidir. Disiplinlerarasılık, Birleşik Krallık'ta 1800'lerin başından itibaren üniversiteler tarafindan zorunlu olan ve gittikçe artarak genişleyen bir yöntemdir. Politik olarak, kurumsal desteğe sahiptir (Brook, Mussgnug ve Pieri, 2017: 381). Disiplinleraras1 programların tematik bir şekilde anaokulu çă̆ öğretme deneyiminden itibaren kullanılması ve yaygınlaştırılmasının önemi büyüktür. Bilgi edinme, anlama becerisinin gelişmesi erken yaşlardan itibaren öğretilmeli ve desteklenmelidir (Akins ve Akerson, 2002: 481). Anaokulu çağg çocuklarının çizme, karalama, görme, algılama gibi duyularının gelişmesinde direk etkisi olan sanat alanı, ilerleyen zamanlarda da bireyin algı dünyasında önemli gelişimler meydana getirmesi açısından 
değerlidir. Sanatın direk olarak etkisi, tasarım dünyasında da kendini göstermektedir. Temel sanat eğitimi dersleriyle tasarım kavramı üzerinde ayrıntılarıyla durularak, özgün tasarımlara ulaşmadaki düşünceden sonuca kadar olan her aşamanın öğretimi yapılmaktadır. Tasarım kavramı, yalnızca sanat alanında değil, günlük yaşamda karşılaşılan her türlü nesnel oluşumdan, teknoloji alanına kadar her alanda yer almaktadır.

Çoğu tasarım programında olduğu gibi, Yeni Medya Tasarım programı, beşeri bilimler için temel disiplinlerden yararlanmaktadır. Çeşitli araştırmalar için sanat tarihi, ileri beşeri bilimlerle işbirliği halindedir. Yeni Medya Tasarımı programı, görsel tasarım, animasyon, programlama, kullanıcı arayüzü ve deneyim tasarımı alanlarıyla direk olarak etkileşim içindedir (Nae, 2017: 840). Bilgiyi işleyen bu dijital dünyada renklerin alg1 problemini, zihinde yarattığı psikolojik etkiyi bilmeden, tasarlama sürecine başlanması, sağlıklı ve düzenli tasarımlar yapılmasına engelleyici bir unsurdur.

Bilgisayar sanatının ilerleme sürecinde, yirminci yüzyılın ikinci yarısının başında ortaya çıan gelişmeler, matematikle iç içe geçişe sebep olmuş, böylece geometriden ilham alan yeni sanat formları meydana gelmiştir (Garousi ve Kowsari, 2012: 215). Sanat matematik ilişkisinden başka, özellikle tıp alanında da bazı ortak çalışmalar yapılmakta ve olumlu yansımaları gözlemlenmektedir.

Özellikle Nöroloji literatüründe sayısız vaka bildirim raporlarına göre çeşitli bireylerin sanat üretimleri sonucunda nörolojik hastalık düzeylerinde değişimler meydana gelmiştir. Bu raporlar, beyin lezyonlarıyla, sanat eserleri arasındaki bağlantıyı ortaya koymaktadır. Bu durumun gelişim süreci, sanat terapisi adı verilen bir etkinlikle sağlanmaktadır. Tedavi sürecinde sanatsal tezahürleri, çeşitli psikoloik yönlerle irdeleyerek dinamik bir bakış açısı aktif edilmektedir. Sanat terapisi eğitimi almış bir psikiyatr ve nöroloğun aynı vaka üzerinde çalışması, disiplinlerarası takım toplantıları düzenlemeleri, sorunların çözümünde karşılıklı etkileşim gücünü artırması açısından önemlidir. Sanat terapisi ve nöroloji farklı geleneklerden gelmiş gibi görünsede aynı dile sahip olmaları ve bütünleşmeleri mümkündür. Hasta bakımına ve iyileşme sürecine katkı sağlayacak çalışmalar, disiplinlerarası çalışma prensipleriyle dikkate değer düzeydedir (Safar ve Press, 2011: 96). Sanat terapisinin nörolojiye sağladığı katkının yanında psikoterapi, antropoloji ve benzeri alanlarla da disiplinlerarası bir etkileşim olduğu muhakkaktır. Sanat alanını kavramsallaştırma, sanat terapistlerini metaforik olarak disiplinlerarası bir yaklaşıma yanaştırmaktadır. Görsel sanat ve psikoterapi arasındaki bu melez durum, "sanat terapisi" olarak ifade edilmektedir. Sanat terapisi, sanat ve terapi arasında soyutlanmış bir kavramdır (Bucciarelli, 2016: 152). Bu iki kavramın birleşmesiyle oluşturulan bu yeni alan, psikolojik değişimleri kontrol eden, araştırma verilerinin ortaya çıkmasına olanak sağlayan yeni bir disipline dönüşmüştür. Bu disiplin, diğer disiplinlerle birleşerek sorunları çözmede etkin bir rol oynamaktadır. Bu sorunların çözümünde ana rol, bireysel deneyim kavramıyla tekilleştirilerek kişiye özgü bir gelişim veya araştırma eğilimine dönük bir model üzerinde durmaktadır.

Bireysel deneyim, yapılanma, aynı zamanda benlik etrafındaki merkezi sorunları modernizm ve postmodernizm düşüncede bireysellik olarak algılamakta, ona göre bir form kazandırmaktadır (Pascual, 2013: 68). 


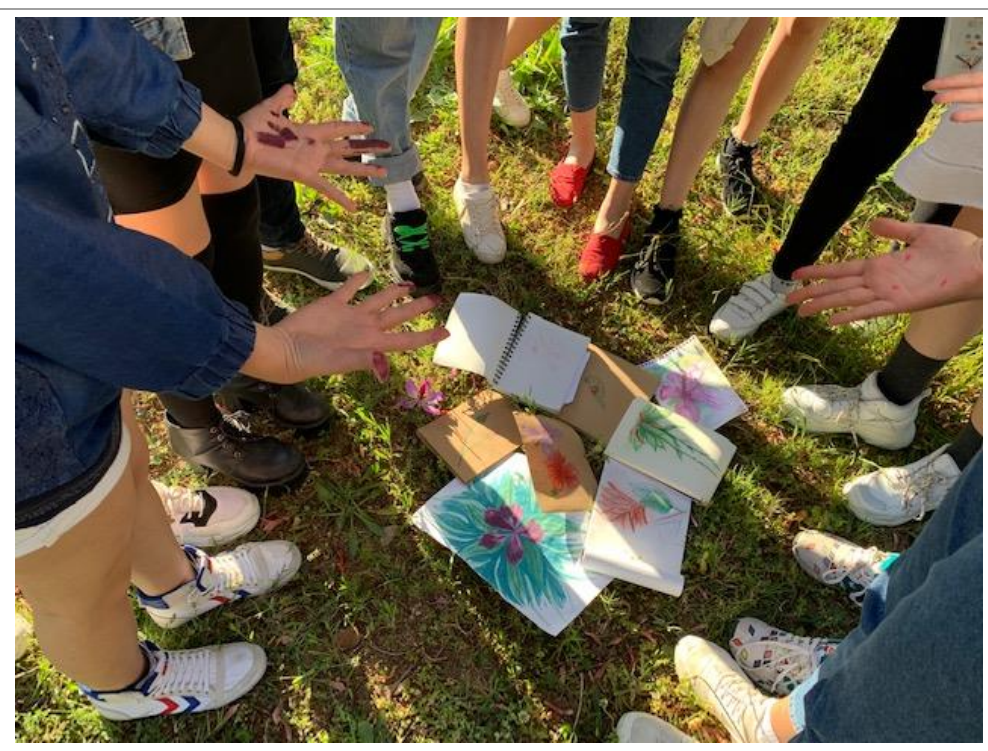

Görsel 2: Doğada sanat terapi.

Sanatın farklı yönlerde ürünler verdiği resim ve müzik alanı bağımsız gibi görünmesine rağmen aynı estetik (günün anlayışına göre), felsefik hedeflere ve kaygılara dayanmaktadır. Özellikle de tüm sanat alanlarında işin içine tasarım/kompozisyon kaygısı girdiğinde, kökten birbirlerine bağlandıkları düzenleme öğelerinin, yaratıcı sürecin kaygısını taşımaktadır. Kullanılan malzeme, dil değişse de temelde aynı kaygılara sahiptirler (Özdemir, İz-Bölükoğlu, Şentürk, 2015). Disiplinlerarası programların ana birleşme noktaları, belirlenmiş kavramlar üzerinden ortak çalışmalar yapma biçimi olarak görülmektedir. Temel sanat eğitiminin önemi, bu kavramların görsel nesnelere nasıl yansıdı̆̆ı, sanatçıların getirdiği farklı bakış açılarıyla irdelenen bir nesnel özellik haline dönüşme biçimlerinin, somut varlıklarının incelenmesini kapsamaktadır. Temel sanat eğitimi bu nedenle hem teorik anlamda hem de uygulama anlamında farklı içeriğe sahip aktif ve dinamik normlara sahip bir derstir.

Uygulamaya dayalı araştırmaların hemen hepsinde içsel bir disiplinlerarasılık özelliği bulunmaktadır. Bilgi işlem teorileri için önemli olan iddia budur (Cazeaux, 2008: 127). Disiplinler arasındaki ortak projeler, sanat eğitiminde özellikle lisansüstü öğrenciler açısından dikkate değerdir. $\mathrm{Bu}$ önem, duyusal bütünleşme ve öznel deneyimle birlikte araştırmacıyı daha etkin kılarak, belirli bir olgunluk düzeyine ulaştırabilir (Bloomgarden ve Schwartz, 1997: 279). Ancak sadece bilgi işlem teorileri değil, aynı zamanda tarih alanları açısından da disiplinlerarası programların etkileşim içinde olması görsellik açısından gereklidir.

Öğrenciler, tarihsel bağlantılar ve toplulukların ilișkilerini anlamada, çözümlemede farklı programların bütünleşmesini öğretim yöntemleri açısından olumlu olarak, öğrenim süreçlerine yansıtabilmektedir. Her yöntemin kendine özgü tarihi, amacı ve sonuçları bulunmaktadır. Sanat eğitiminin daha postmodern bir yapıya sahip olması kesinlikle disiplinlerarası çalışmalarla mümkün olabilecektir (Ulbricht, 1998: 17).

\section{Sonuç}

Disiplinlerarası programlara temel sanat eğitimi dersinin entegre edilmesi nokta, çizgi, biçim, renk, leke, doku, değer gibi sanatın temel elemanları ile denge, hareket, ritim, vurgu, bütünlük, zıtlık, çeşitlilik, oran-orantı temel sanat ilkelerinin yüzeyler üzerindeki etkisinin algılanmasına katkı sağlayacaktır. Biyoloji dersinde biyolojik yapıların çiziminde ve hacimlendirilmesinde temel sanat eğitimi dersinin içeriğinde verilecek çizim tekniklerinin faydası azımsanamayacak ölçüdedir. Aynı şekilde matematikte, oran- orantıdan sanatın temellerinin faydalandığı gibi matematik alanında da 
sanatın temel dinamiklerinin katkı sağlayacağı düşünülebilir. Bucciarelli (2016: 15)'nin de ifade ettiği gibi; sanat terapisinin nörolojiye sağladığı katkının yanında psikoterapi, antropoloji ve benzeri alanlarla da disiplinlerarası bir etkileşimi olduğu muhakkaktır. Psikoterapi alanında temel sanat eğitimi dersinin, tasarım odaklı yaklaşımıyla disiplinlerarası çalışmalara katkı sağlayacağ düşünülebilir.

Biçimlerin analizi ile problem çözme odaklı düşünme arasındaki ilişkinin çözümlenmesiyle sorunlara bakış ve çözüme odaklanmada katkı sağlayacaktır. Temel sanat eğitiminin bireylere sağladığı görmeyi öğrenmenin, yaşama sağlayacağ 1 katkılar tartışılmazdır. Doğa bilimcilerin doğa analizleriyle, yine temel sanat eğitiminin doğa destekli çalışmaları birbirine katkı sağlayacak niteliktedir. Bu anlamda disiplinlerarası çalışmalarda, temel sanat eğitiminin getireceği katkılar şüphesiz olumlu düzeyde olacaktır.

Sanat eğitiminin disiplinlerarası çalışmalarda katkıları şüphesizdir. Aynı zamanda görsel okur-yazarlık kazandırması da toplumsal kültür oluşumunda önem taşımaktadır. Dünyayı hakkıyla sorgulayan ve görebilen, analiz edebilen bireyler yetiştirmek yine temel sanat eğitimi ile mümkün olacaktır.

\section{Kaynakça}

Akins, A., Akerson, V. L. (2002). Connecting science, social studies, and language arts: an interdisciplinary approach. Educational Action Research, 10(3): 479-498.

Berger, J. (2016). Görme biçimleri. Metis Yayınevi.

Bequette, J., Brennan, C. (2008). Advancing media arts education in visual arts classrooms: addressing policy ambiguities and gaps in art teacher preparation. Studies in Art Education, 49(4):328-342.

Bloomgarden, J., Schwartz, D. (1997). Creative art therapy/special education in higher education: toward an interdisciplinary model. Art Therapy, 14(4): 279-281.

Brook, C., Mussgnug, F., Pieri, G. (2017). Italian studies: an interdisciplinary perspective. Italian Studies, 72(4): 380-392.

Bucciarelli, A. (2016). Art therapy: a transdisciplinary approach. Art Therapy, 33(3):151-155.

Cazeaux, C. (2008). Inherently interdisciplinary: four perspectives on practice-based research. Journal of Visual Art Practice, 7(2): 107-132.

Clarke, J. (2014). Disciplinary boundaries between art and anthropology. Journal of Visual Art Practice, 13(3):178-191.

DeMarrais, E., Robb, J. (2013). Art makes society: an introductory visual essay. World Art, 3(1): 322.

Garousi, M., Kowsari, M. (2012). Fractal art and postmodern society. Journal of Visual Art Practice, 10(3):215- 229.

Genç, A., Sipahioğlu, A. (1990). Görsel algılama "sanatta yaratıcı süreç”. Sergi Yayınevi.

Keane, J. (2008). Constructing the conditions of and environments for interdisciplinary research on perception and action. Ecological Psychology, 20(4): 343-360.

Kennedy, M. (2009). An examination of critical approaches to interdisciplinary dance performance. Research in Dance Education, 10(1):63-74.

Kırışoğlu, O.T. (2002). Sanatta ĕ̆itim. Pegem yayınevi. 
Nae, H. J. (2017). An interdisciplinary design education framework. The Design Journal, 20(sup1):835-S847.

Özdemir, A., İz-Bölükoğlu, H., Şentürk, N. (2015). Temel sanat eğitiminde disiplinlerarası yaklaşıma dayalı (müzik destekli) uygulamanın öğrenci tutum düzeyine etkisi. Ekev Akademi Dergisi, 19(63):15-29.

Özkök, A. (2005). Disiplinlerarası yaklaşıma dayalı yaratıcı problem çözme öğretim programının yaratıcı problem çözme becerisine etkisi. Hacettepe Üniversitesi Eğitim Fakültesi Dergisi, 28: 159-167.

Pascual, B. B. (2013). (Capturing) intention: The life of an interdisciplinary research project. International Journal of Performance Arts and Digital Media, 9(1): 61-81.

Rhodes, A. M. (2006). Dance in interdisciplinary teaching and learning. Journal of Dance Education, $6(2): 48-56$

Ross, T. (2006). Aesthetic autonomy and interdisciplinarity: a response to Nicolas Bourriaud's 'relational aesthetics'. Journal of Visual Art Practice, 5(3):167-181.

Safar, L. T., Press, D. Z. (2011). Art and the brain: effects of dementia on art production in art therapy. Art Therapy, 28(3): 96-103.

Ulbricht, J. (1998) Interdisciplinary art education reconsidered. Art Education, 51(4):13-17.

Yang, A.S. (2011). Interdisciplinarity as critical inquiry: visualizing the art/bioscience interface. Interdisciplinary Science Reviews, 36(1):42-54. 